\title{
The irresistible solution: rationale and risks of extending water limits through desalination in the case of Gotland, Sweden
}

\author{
Sophia Speckhahn ${ }^{1}$ \\ Ellinor Isgren \\ Lund University, Sweden
}

\begin{abstract}
Water resources are under increasing pressure, and there are tensions between increasing demand and the natural limits to potable water supply. Authorities must find solutions that fulfil societal demands without compromising environmental integrity. As one way to counteract water deficits, desalination has evolved as an attractive solution. This technology is contested and associated with a variety of social, environmental and economic consequences; yet it is increasingly used. In Sweden, the technology is rare but recent droughts have spurred interest. On the island of Gotland, where Sweden's first larger desalination plant was inaugurated in 2016, we examine the perceived benefits and drawbacks of desalination as well as the decision-making process that led up to its implementation. Through qualitative analysis of public documents and stakeholder interviews, we identify mechanisms that contributed to desalination becoming a favored solution. We find that it is associated with a number of benefits that are in line with broader development goals, against which its drawbacks are considered to be acceptable or externalized. Desalination extends natural limits to permit development, delaying deeper social and economic restructuring. Rather than arguing against desalination per se, we emphasize the risk of the depoliticization of water supply through technocratic decision-making, the normalization of scarcity and certain technologies, and the urgency that builds around increasing water supply 'at any economic cost.' These tendencies obscure drawbacks, limitations and conflicting interests. They foreclose the questioning of resource intensive development. In order to invoke transformation towards longterm sustainability of Gotland's water supply, policy-makers should seek to diversify their sources of knowledge and encourage more open democratic debate around alternative regional development pathways.
\end{abstract}

Keywords: desalination, natural limits, water scarcity, Gotland, political ecology, technocracy, depoliticization, normalization

\section{Résumé}

Les ressources en eau subissent une pression croissante et il existe des tensions entre la demande croissante et les limites naturelles de l'approvisionnement en eau potable. Les autorités doivent trouver des solutions qui répondent aux exigences de la société sans compromettre l'intégrité environnementale. Le dessalement est un moyen attrayant de remédier aux déficits en eau. Cette technologie est contestée et associée à diverses conséquences sociales, environnementales et économiques; pourtant, il est de plus en plus utilisé. En Suède, la technologie est rare mais les sécheresses récentes ont suscité l'intérêt. À l'aide du cas de l'île de Gotland, où la première grande usine de dessalement de Suède a été inaugurée en 2016, nous examinons les avantages et les inconvénients perçus du dessalement ainsi que le processus décisionnel ayant conduit à sa mise en œuvre. Grâce à l'analyse qualitative de documents publics et aux entretiens avec les parties prenantes, nous avons identifié les mécanismes qui ont contribué à faire du dessalement une solution privilégiée. Nous constatons qu'il est associé à un certain nombre d'avantages conformes aux objectifs de développement plus larges, contre lesquels ses inconvénients sont considérés comme acceptables ou externalisés. Le dessalement étend les limites naturelles pour permettre le développement, retardant ainsi une restructuration sociale et économique plus

\footnotetext{
${ }^{1}$ Sophia Speckhahn and Dr. Ellinor Isgren, Lund University Centre for Sustainability Studies (LUCSUS), Lund University, Sweden. Emails: ellinor.isgren "at" lucsus.lu.se, sophia.speckhahn "at" gmx.de. The authors wish to thank all study participants for generously sharing their time and insights. The manuscript was improved greatly thanks to the constructive comments from an anonymous reviewer.
} 
profonde. Plutôt que de plaider contre le dessalement en soi, nous soulignons le risque de dépolitisation de l'approvisionnement en eau par la prise de décisions technocratiques, la normalisation de la rareté, la normalisation de certaines technologies et l'urgence liée à l'accroissement de l'approvisionnement en eau «à tout prix économique». Ces tendances masquent les inconvénients, les limitations et les intérêts contradictoires. Ils excluent la remise en cause du développement utilisant beaucoup de ressources. Afin de susciter une transformation vers la durabilité à long terme de l'approvisionnement en eau de Gotland, les décideurs devraient chercher à diversifier leurs sources de connaissances et encourager un débat démocratique plus ouvert autour de différentes voies de développement régional.

Mots-clés: dessalement, limites naturelles, pénurie d'eau, Gotland, écologie politique, technocratie, dépolitisation, normalization

\section{Resumen}

Los recursos hídricos se encuentran bajo una creciente presión, además de las tensiones entre el aumento de la demanda y los límites naturales del suministro de agua potable. Las autoridades deben encontrar soluciones que satisfagan las demandas sociales sin comprometer la integridad del medio ambiente. La desalinización se ha desarrollado como una solución atractiva para impedir los déficits de agua. Esta tecnología resulta controversial y se ha asociado con varios efectos negativos tanto sociales, ambientales, como económicos; aún así, su uso se ve en aumento. En Suecia, esta tecnología no es común, pero las recientes sequías han estimulado un nuevo interés en ella. En la isla de Gotland, donde fue inaugurada la primera mayor desalinizadora sueca en 2016, examinamos los beneficios percibidos y las desventajas de la desalinización, así como el proceso de la toma de decisión que llevó a su implementación. Con base en análisis cualitativos de documentos públicos y de entrevistas a diversos actores, identificamos mecanismos que contribuyeron a que la desalinización se convirtiera en la solución preferida. Encontramos que esta práctica está asociada con varios beneficios articulados con objetivos más amplios de desarrollo, frente a los cuales, las desventaja son considerada aceptables o exteriorizadas. La desalinización extiende los límites naturales para así permitir el desarrollo, al retrasar la una profunda reestructuración social y económica. Más que discutir contra la desalinización como tal, enfatizamos el riesgo de la despolitización del suministro de agua a través de la toma de decisiones tecnocrática, la normalización de la escasez y de ciertas tecnologías, y la urgencia que se forma alrededor del suministro de agua "a cualquier costo económico." Estas tendencias opacan los obstáculos, las limitaciones y los intereses en conflicto. Con el fin de acoger una transformación hacia la sustentabilidad del suministro de agua a largo plazo en Gotland, quienes formulan políticas deben buscar la diversificación de sus fuentes de conocimiento e incentivar el debate democrático abierto con respecto a las vías alternativas de desarrollo regional.

Palabras clave: desalinización, límites naturales, escasez de agua, Gotland, ecología política, tecnocracia, despolitización, normalización

\section{Introduction}

Access to a sufficient amount of potable water is a prerequisite for the wellbeing of humanity, and a variety of phenomena put pressure on water resources (World Water Assessment Programme 2012). Freshwater supply is globally limited and is therefore sometimes referred to as a 'Planetary Boundary' (Steffen et al. 2015). Context-specific factors shape water conditions in a locality, reflecting its past and present (Swyngedouw 2009). Water management involves complex interactions, often with conflicting interests between water uses and functions. These tensions create a need for decision-making processes capable of taking into account the manifold interests and concerns of water users, as well as the many roles of water in the environment (Molle $e t$ al. 2008).

Sweden is normally associated with an abundance of water, yet local water shortages occur which threaten the water supply for people and ecosystems, and some regional and local authorities experience pressure to guarantee future water security. The island of Gotland in southeastern Sweden is one such region, where recent shortages have stimulated discussions about how to safeguard water resources. These led to the opening of the Herrvik desalination plant on the island's east coast in summer 2016. The plant converts saltwater from the Baltic Sea into drinkable tap water, complementing the municipal groundwater-based supply (Region Gotland, n.d.-b). While there is enough water for current needs on the island, capturing it and making it accessible for human consumption is problematic (Dahlqvist et al. 2017). The question we address is why 
desalination was considered, how this decision was made, and what long term consequences does it have for water governance in the region?

Desalination is controversial because of its direct environmental consequences. These include high energy consumption, and impacts on marine ecosystems. Indirect influences include a sense of security that can reduce attention to water demand, enabling further consumption and development (Meerganz von Medeazza 2005). Desalination is contested by those who argue that rather than increasing supply, the goal should be to reconsider its use and improve the benefits per unit of water used (Gleick 2003). Supply-oriented solutions potentially lead to the postponement of demand side measures, pressuring local water systems (Kallis 2008; Meerganz von Medeazza 2005). Nonetheless, desalination is on the rise globally, and interest is growing in Sweden - not least after the 2018 summer drought (Andersson 2018).

The aim of this article is to contribute to the growing debate around desalination, and more broadly supply-oriented approaches in water management, through the case of Gotland. We analyze the implementation of desalination against a backdrop of the historical production of water scarcity in Gotland, and its perpetuation through a development strategy that centers on water-intensive sectors. The article addresses the following overarching question: why did Gotland's authorities decide to complement the island's water supply with a desalination plant, despite its known controversies? Aiming to provide a critique of desalination in this context (that is, to understand its appeal but also its limits and contradictions), we structure the analysis around three issues:

1) the perceived societal gains of desalination

2) the environmental and social problems which arise from, or are left unaddressed by, desalination

3) the decision-making mechanisms that enabled its implementation.

Being the first study of this kind in Sweden (and, to our knowledge, the Nordic countries) we treat it as a critical case of how desalination and similar supply-oriented solutions can gain ground in other world regions thought to be water-rich - in part as a response to climate change, but equally as a result of long-entrenched regional economic development pathways.

\section{Theoretical and methodological approach}

\section{The case: desalination on Gotland}

The Herrvik desalination plant (Figure 1) was inaugurated on Gotland's east coast in the summer of 2016 and is Sweden's first larger desalination plant for municipal supply (Region Gotland, n.d.-b). The plant uses reverse osmosis to convert up to $20 \mathrm{~m}^{3}$ of seawater/hour into drinkable water, which is distributed to surrounding communities (Region Gotland, n.d.-b). A second plant in Kvarnåkershamn on Gotland's west coast is under construction and will supply drinking water for the south of the island (Region Gotland 2018). This second facility will have a maximum production capacity of 7,500 $\mathrm{m}^{3}$ per day (Region Gotland 2018), which will make it northern Europe's largest (SVT 2018). Desalination is meant as a complement to existing water resources, and to avoid the overuse of groundwater and aquifers (Region Gotland 2014).

\section{Theoretical framework}

Our approach is rooted in a critical realist perspective and situated in the field of political ecology. A critical realist understanding presumes the existence of a reality independent from our understanding and conceptualization of it, wherein scientific knowledge of the world is possible, and can serve as an instrument to change and potentially improve existing conditions (Benton and Craib 2010). This requires systematic inquiry aimed at understanding causality, as well as critical questioning of commonly accepted explanations (Forsyth 2001; Sayer 2000). Drawing on a critical realist understanding of how causal mechanisms interact in ways that are always context-specific (Sayer 2000) we set out to understand how different conditions, conceptualizations 
and decision-making processes interacted to produce a historically and geographically contingent outcome: the recent implementation of desalination in Gotland.
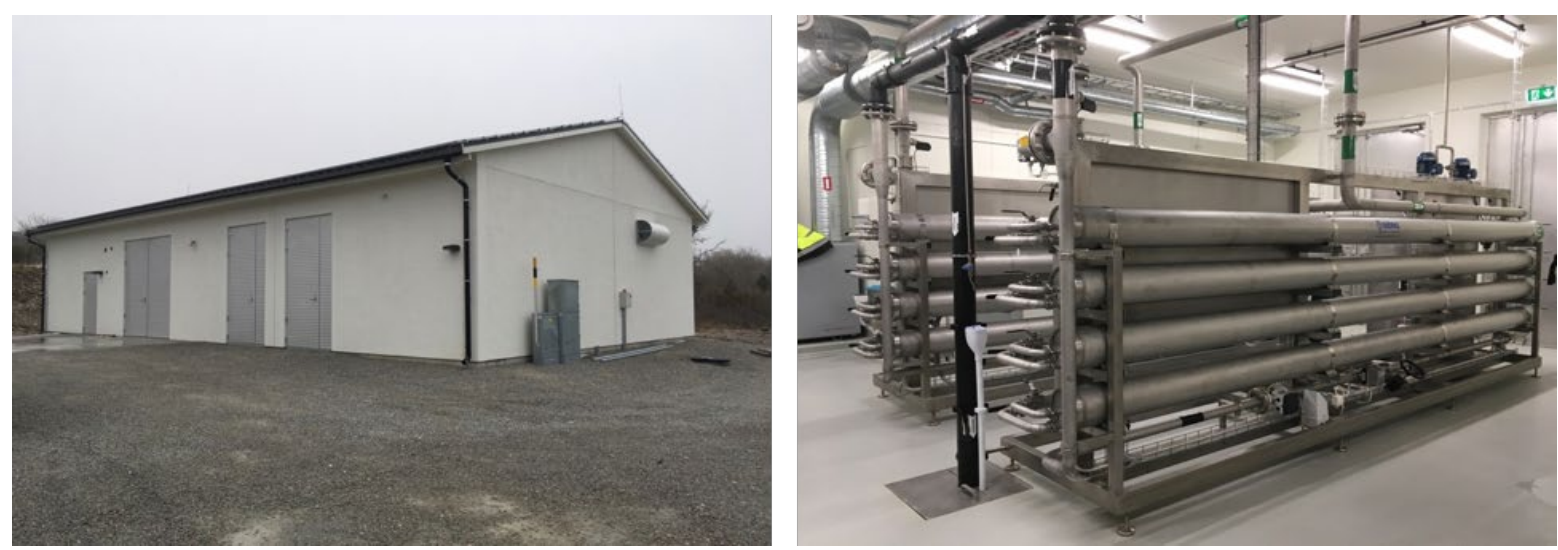

Figure 1: Desalination plant in Herrvik from the outside (left) and the membrane filter inside (right).

Furthermore, the study draws on political ecology and especially the 'hydro-social-cycle' (Swyngedouw 2009). Water's physical and social components constitute the 'hydraulic environment.' It is not enough to examine the physical characteristics of water and its material flows to understand problems related to water supply and use; one must also investigate the social and political settings determining these characteristics and flows. Political ecology draws attention to the political interests and processes associated with environmental challenges such as resource degradation, scarcity and allocation (Gezon and Paulson 2005), often investigated in the global South (Forsyth 2003) but equally relevant in the global North (Robbins 2002). Political ecology problematizes 'apolitical' understandings and explanations of environmental challenges, and depoliticizing discourses and decision-making processes (Loftus 2009; Robbins 2002). An important theme is the discursive framing of nature rather than human activities and social relations as the source of water scarcity and crisis (Bakker 2000; Kaika 2006). Relegating causes to the realm of nature is "is a well-known and much-used strategy to depoliticize water problems, placing contentious questions of distribution outside of the domain of public debate" (Zwarteveen and Boelens 2014). As we will elaborate more on in Section 4, these are issues frequently raised with desalination, with the depoliticization of crises and technocratic ${ }^{2}$ decision-making (see Kallis 2008; Knights et al. 2007; Usher 2018; Williams 2018). Against this background we emphasize the reasoning behind the apparent necessity to install desalination on Gotland, as well as the institutional and practical dimensions of the political decision-making process.

\section{Research design and methods}

A single case study allows for in-depth analysis of a phenomenon in a specific location (Bryman 2012). We approach the Herrvik desalination plant as a critical case, one that has "strategic importance in relation to the general problem" (Flyvbjerg 2006: 229). The plant is comparably small yet it is the first of its kind in Sweden, and it is a door opener for this technology in other Swedish locations suffering water scarcity, as the second, larger plant on Gotland illustrates (Region Gotland 2018). Another was opened on the neighboring island of Öland in 2017 (Fredelius 2017). Beyond Sweden, the case provides insights of particular relevance to places where this technology remains relatively novel, and more generally contributes to better understanding of the development and spread of supply-oriented technological solutions in natural resource management.

\footnotetext{
${ }^{2}$ This refers to processes where "ever more influence in political decision-making to those with particular forms of scientific and/or technological expertise" (Machin \& Smith 2014: 50).
} 
Empirically, the study builds on document analysis, interviews and observations. This provided access to multiple perspectives and types of information, and enabled triangulation (Yin 2009). Six documents were analyzed (Table 1), all published by Gotland authorities. ${ }^{3}$ Some were written several years before desalination was implemented, which offers insight into how framings and understandings have changed over time. In addition to these documents, information regarding the decision-making and construction processes was retrieved from protocols of Region Gotland's technical committee, in charge of planning and constructing the plant (16 protocols between 2013 and 2016).

Document analysis was combined with semi-structured face-to-face interviews and observations in order to understand what the process had entailed, verify information from documents, and explore views held by different stakeholders. Seven interviewees were selected using purposive sampling (Bryman 2012) informed by background research on the decision-making process and public debate (see Table 2; anonymized). They represent planning, administration and decision-making entities, the agriculture and tourism sectors (both important water users of high historical and cultural relevance within Gotland's socioeconomic context), and local organizations concerned with water issues. These groups are not homogeneous and the small number of interviewees may not have done justice to the complexity of the case; still the diversity increases the likelihood of covering the most relevant arguments. Interviews were conducted in March 2017 and lasted between 45 and 125 minutes. In addition, a group discussion took place with engineers from Region Gotland's technical committee, focusing on specific questions related to their expertise. Finally, site visits took place at the Visby waterworks, the Herrvik plant and the wetland restoration project 'Aquabrava' initiated by the association 'Jordgumman.'

\begin{tabular}{|l|l|}
\hline Document & Reference \\
\hline Water plan Gotland municipality & Gotlands Kommun (2005) \\
\hline Vision Gotland 2025 & Gotlands Kommun (2008) \\
\hline $\begin{array}{l}\text { Build Gotland: overview plan for Gotland } \\
\text { municipality (chapter 8 on water and } \\
\text { wastewater) }\end{array}$ & Gotlands Kommun (2010) \\
\hline $\begin{array}{l}\text { Long-term water and wastewater plan } \\
\text { Gotland 2014-2022 and its 2016 revision }\end{array}$ & $\begin{array}{l}\text { Region Gotland (2014) and Region Gotland } \\
\text { Teknikförvaltningen (2016b) }\end{array}$ \\
\hline Pre-study for Visby's future water supply & Region Gotland Teknikförvaltningen (2016a) \\
\hline $\begin{array}{l}\text { Fact sheets for Herrvik and } \\
\text { Kvarnåkershamn desalination plants }\end{array}$ & Region Gotland (2018, n.d.-b) \\
\hline
\end{tabular}

Table 1: Documents used for analysis.

Data was analyzed through a combined content and thematic analysis (Bowen 2009). Documents and interview transcripts were analyzed by allocating statements and information into categories based on the research questions. Relevant text passages were coded and thematized, allowing for identification of common patterns and recurring arguments (Bowen 2009).

\footnotetext{
${ }^{3}$ Gotland Municipality [Gotlands Kommun] was renamed Region Gotland in 2011 but refers to the same administrative entity. The technical administration [Teknikförvaltningen] is part of Region Gotland.

${ }^{4}$ This document is not publicly available but was provided by one of our contacts from Region Gotland.
} 


\begin{tabular}{|l|l|l|}
\hline Category & Acronym & Organisation \\
\hline Public sector & Politician MP & $\begin{array}{l}\text { Member of Regionfullmäktige [local parliament] Region } \\
\text { Gotland and chair of environmental and health board, } \\
\text { Miljöpartet [Green Party] Gotland }\end{array}$ \\
\cline { 2 - 3 } & $\begin{array}{l}\text { County } \\
\text { Administrative Board }\end{array}$ & $\begin{array}{l}\text { Responsible for drinking and groundwater questions at } \\
\text { Länsstyrelsen Gotland [County Administrative Board] }\end{array}$ \\
\hline $\begin{array}{l}\text { Private } \\
\text { sector }\end{array}$ & Representative LRF & $\begin{array}{l}\text { Vice President of Lantbrukarnas Riksförbund [National } \\
\text { Farmers Association] Gotland }\end{array}$ \\
\cline { 2 - 4 } $\begin{array}{l}\text { Other } \\
\text { initiatives }\end{array}$ & Representative GFB & $\begin{array}{l}\text { Managing Director of Gotlands Förenade Besöksnäring } \\
\text { [Gotland's united tourism industry] }\end{array}$ \\
\cline { 2 - 4 } & Aquabrava project & $\begin{array}{l}\text { Chief of Östra Gotlands Vattenråd [water council, East } \\
\text { Gotland] }\end{array}$ \\
\cline { 2 - 4 } & $\begin{array}{l}\text { Ek. för. Jordgumman, Aquabrava initiative of wetland } \\
\text { restoration (citizen initiative) }\end{array}$ \\
\cline { 2 - 3 } & Representative NF & $\begin{array}{l}\text { Secretary of Naturskyddsföreningen [Society for Nature } \\
\text { Conservation] Gotland }\end{array}$ \\
\hline
\end{tabular}

Table 2: Key informants for semi-structured interviews, and their positions.

\section{The production and perpetuation of water scarcity in Gotland}

Gotland is located around $90 \mathrm{~km}$ off Sweden's east coast and has an area of about $3,140 \mathrm{~km}^{2}$, making it the second largest island in the Baltic sea (Figure 2). The population in 2017 was around 58,000 (Region Gotland 2017) and the regional development plan forecasts an increase to around 65,000 by 2025 (Gotlands Kommun 2008). However, the island is a popular holiday destination and tourism drastically increases the number of water users, especially during summer - in 2015, around 931,000 night guests were recorded (Region Gotland 2016: 24). Summer is also when supply of water is at its lowest. Gotland has faced seasonal but recurring water security difficulties in recent years: groundwater levels are decreasing, as in southeastern Sweden generally, and reached historically lows in March 2016 (Geological Survey of Sweden 2016).

Groundwater from 22 municipal aquifers accounts for about two thirds of the island's municipal water supply, providing 4,000,000 m³ year to Gotland's residents (Dahlqvist et al. 2017). Population, holiday dwellings, water sources and water infrastructure are unevenly distributed on the island and an additional demand of $1,000,000$ to $1,500,000 \mathrm{~m}^{3}$ of water per year is estimated (Dahlqvist et al. 2017). The pipeline network for municipal water supply was mostly built between the 1950s and 1970s and in some areas, renewal rates need to increase (Gotlands Kommun 2005). The strategy in Gotland's long-term water and wastewater plan from 2014 suggests building a northern grid and a southern grid on the island, eventually linking these together (Region Gotland 2014). Additionally, $37 \%$ of Gotland's population is not connected to the municipal grid and relies on individual water withdrawals (Region Gotland 2014: 7).

Gotland's geology is characterized by fractured limestone bedrock covered by thin layers of soil, without major water-bearing strata (Region Gotland, n.d.-a). This limits storage capacity (Dahlqvist et al. 2017). Water is usually transported downward in small fissures, reaching the groundwater table within minutes or hours, and is accessible across the island (Region Gotland, n.d.-a), leaving little time for intervention in case of a problem. Both factors make Gotland's groundwater highly vulnerable and sensitive to contamination.

Gotland's water security problems are not solely caused by natural conditions. In the late 18 th and early 19th century, extensive drainage and ditching activities exploited $70 \%$ of Gotland's wetlands (Figure 3) to enable agricultural expansion (Martinsson 1997). Given the hydrologic role of wetlands, there is a direct connection between these activities and the challenges experienced today. Drainage caused a decline in water storage capacity and groundwater recharge, thus resulting in lowering of the water table (Zucchetto and Jansson 1985). High amounts of surface water runoff during the spring flood cause many rivers to dry out over summer, which impacts not only water supply for human use, but also many organisms and species (Martinsson 1997). 
Wetland drainage thus had immense influence on Gotland's water system, with two important implications for contemporary discussions. First, current problems are to some extent human-made. Second, potential water problems were recognized at least 30 years ago, thus the consequences were predictable and could have been addressed earlier.

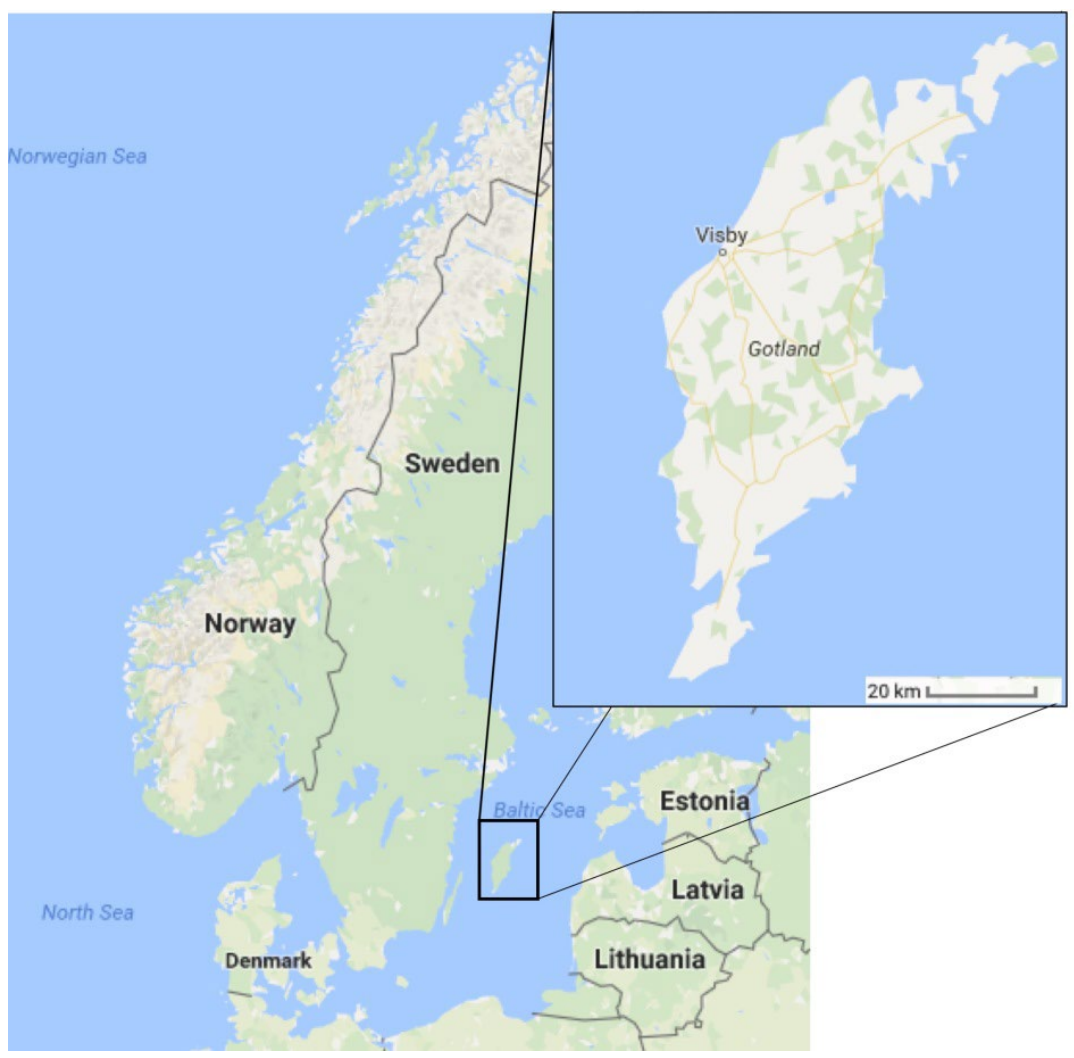

Figure 1: Location of Gotland. Own illustration based on Google Maps.

Today, around two thirds of Gotland's water supply is retrieved from groundwater and the remaining third from surface water. The industrial sector is the biggest water user followed by households (which includes water used by tourists) and agriculture (see Figure 4). Large industrial users of municipal water are found in food processing, and the cement industry (Sveriges Radio 2016), though much of the industrial water is drainage from mines and quarries. Both agriculture and tourism are highly important economic activities on the island, and both are highly dependent on water in sufficient amounts and quality. In 2010, $34.9 \%$ of Gotland's land was used for agriculture (Statistics Sweden 2013: 41) which together with forestry and fishing accounted for $12.4 \%$ of jobs in 2007 (Gotlands Kommun 2010: 65). Water is used for crop irrigation and livestock. Tourism is essential to provide jobs for the local population by creating demand for accommodation, restaurants, shopping and other activities (Gotlands Kommun 2010). Considering the accommodation revenue per capita, a few years ago Gotland was highest ranked in regards to the economic significance of tourism (Swedish Agency for Economic and Regional Growth 2011: 39). The importance of tourism is not coincidental; in reaction to declining employment from agricultural mechanization, purposeful local and national policies have been implemented since the 1960s to counteract depopulation. This has included strengthening of the tourism industry (Zucchetto and Jansson 985). 
Two additional aspects are important to consider in this context. One is that, as mentioned above, only about two thirds of the population is connected to the municipal water and sewage grid. A significant share of the population relies on individual water withdrawal from wells (Region Gotland 2014: 7). The other is that planning for Gotland's future water supply needs to be aligned with climate change impacts. Asp et al. (2015) predict a temperature increase of $3-5^{\circ} \mathrm{C}$ for Gotland until the end of the century, as well as an increase in precipitation of 20-30\% compared to 1961-1990 (Asp et al. 2015). While temperature rise and a prolonged growing season could lead to higher water requirements, the expected increase of precipitation could be an advantage.

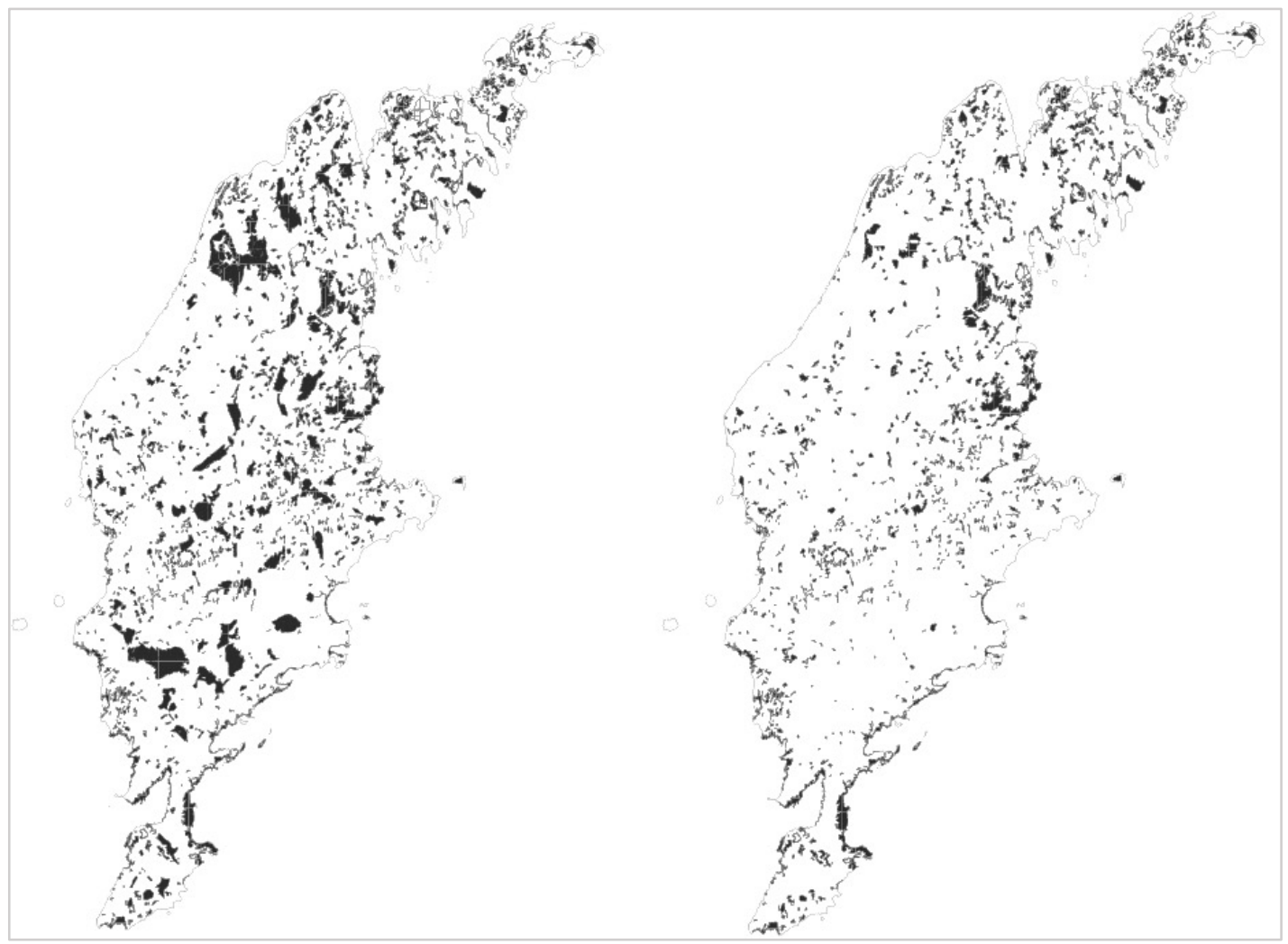

Figure 3: Wetlands on Gotland in 1700 (left) and in 1996 (right) republished with permission from Martinsson (1997: 22-23).

\section{Desalination to the rescue? A controversial solution to water scarcity}

As the vast majority of Earth's water consist of seawater, the idea to use it for human consumption is not new. Indeed it has been traced as far back as Aristotle (Williams and Swyngedouw 2018) and multiple efforts have since been made to transform seawater into freshwater, for example in the 17th century to ensure water supply on ships (Greenlee et al. 2009). Today, various desalination technologies are widely applied, especially in the Middle East (Greenlee et al. 2009) and its use is expanding globally due to increasing water demands, cost reductions, and growing concerns about climate change (Feitelson and Jones 2014; Ghaffour, Missimer, and Amy 2013). The current global capacity is estimated at around $92.5 \mathrm{~m}^{3} /$ day (Zarzo and Prats 2018), providing water to at least 300 million people in 150 countries (March 2015: 233). The preferred technology nowadays is reversed osmosis; creating pressures higher than the osmotic pressure of a salt solution to force the 
liquid through a membrane, filtering out salt ions (Miller 2003). Desalination is not a new technology, but its uneven global spread means that there are many places where it is still regarded as novel.

\section{Freshwater use on Gotland (1000 cubic meters), 2015}

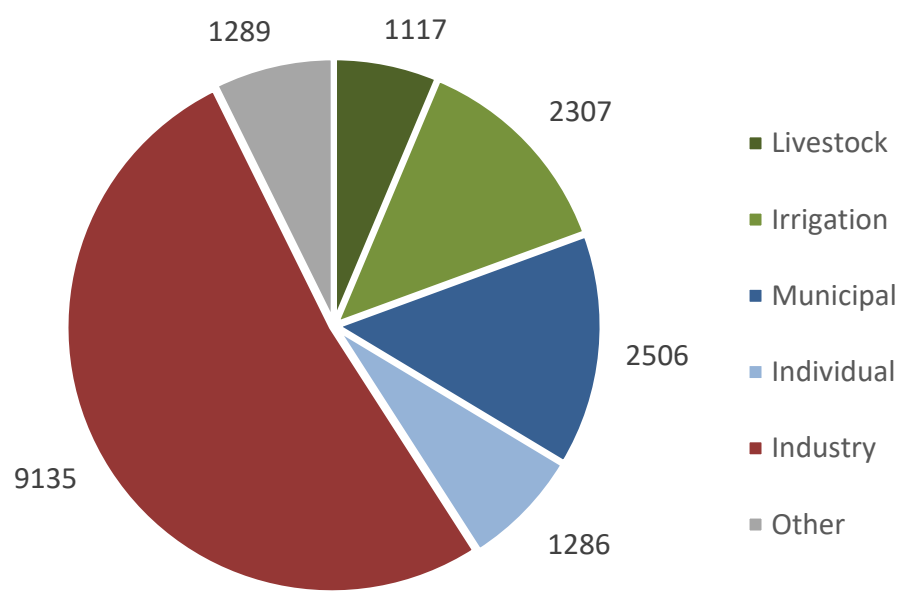

Figure 4: Freshwater use on Gotland in 2015, divided between different uses: agriculture (livestock and irrigation) in green (19\%), households (municipal and individual) in blue (21\%), industry in red (52\%), and other uses in grey (7\%). Source: Statistics Sweden 2019. Note that a large proportion $(85 \%)$ of water attributed to industry is drainage water.

Desalination has several advantages over conventional water supply measures. The infinity of the ocean's water supply with no reliance on precipitation make supply in principle endless, and easily controllable (Ghaffour et al. 2013). Seawater is seen as 'free' and not subject to property rights or constrained by cultural values (Swyngedouw 2013). Pressure is reduced on groundwater resources (March 2015). Desalination is nonetheless a controversial technology, with a number of direct and indirect effects. In terms of environmental impact, a major criticism is that the process is very energy intensive and therefore increases overall energy consumption (March 2015). The energy need for a specific plant depends on various factors like temperature, salinity and choice of technology (Swyngedouw and Williams 2016), but Lior (2017) states 3-4 $\mathrm{kWh} \mathrm{per} \mathrm{m}^{3}$ of desalinated seawater is needed using reverse osmosis. For the desalination of brackish water (as in the Baltic) energy requirements can drop to $0.5-2.5 \mathrm{kWh} / \mathrm{m}^{3}$ (March 2015: 233). Energy intensity is problematic at a time when mitigation of climate change is a global goal (Anderson et al. 2008; Cooley and Heberger 2013). As Knights et al. (2007) point out, avoiding dangerous climate change requires an overall reduction of energy consumption. March (2015) highlights the paradox of exacerbating climate change while simultaneously depicting desalination as a climate change adaptation strategy. The technique can cause harm where aquatic organisms enter open intakes and discharge of brine affects surrounding marine ecosystems (March 2015; Meerganz von Medeazza 2005). Potential environmental impacts include the physical demand for land, noise, and chemical pollution (Santos Pereira, Cordery, and Iacovides 2009).

Economic and social concerns include high costs. Actual costs of desalination are extremely variable and depend on multiple factors (Miller 2003). For reverse osmosis of seawater, Santos Pereira et al. (2009) report a range of $0.45-0.71 € / \mathrm{m}^{3}\left(0.51-0.81 \$ / \mathrm{m}^{3}\right)$. This raises questions about the affordability and accessibility of desalinated water and the effect of producing "relative scarcities" (March 2015: 238). Cost might not only exclude certain groups or countries, but also encourage additional groundwater pumping, even illegally (Swyngedouw and Williams 2016). Moreover, cost projections are insecure: they could decline due to advances in energy efficiency, or rise with higher energy prices and/or internalization of ecological costs (March 2015). 
Although a major perceived benefit of desalination is its independence from climatic conditions (Knights et al. 2007), desalination makes water supply dependent on energy supply, pricing and variability (Kallis 2008; Swyngedouw and Williams 2016). It can thereby be seen as shifting problems from one scarcity (freshwater) to another (energy), thus postponing problem solving into the future (Swyngedouw and Williams 2016). Ultimately, the actual energy implications of desalination are difficult to project because they also depend on whether it only replaces other sources, or stimulates further resource-demanding growth and development (Cooley and Heberger 2013).

This takes us to the critique that has been expressed about the general approach to solving water scarcity by increasing supply. Dickie (2007) argues that desalination undermines the obligation to use water more thoughtfully, and argues that what is needed is not a new water source but rather a new perspective on water. Indeed, Meerganz von Medeazza (2005) stresses that increasing water supply risks increasing demand and thus intensifying overall pressure on local water systems. The removal of an environmental constraint can also trigger further development with potential consequences for regional sustainability (Meerganz von Medeazza 2005). Kallis (2008) expresses a similar concern, but points out that small plants that are only used temporarily can have a securing effect without necessarily producing these outcomes. This reminds us that the impacts of desalination are contextual in nature, depending on the characteristics of the plant and its social (and environmental) context. For example, based on research in two Latin American cities, Fragkou and McEvoy (2016) show how desalinated tap water does not necessarily reduce demand for bottled water where consumers lack trust in the water supply system.

Finally, there are political aspects related to adoption of desalination that have been subject to debate. Williams (2018) criticizes the overwhelmingly "ageographical and apolitical" understanding of desalination as a solution to water stress within water governance circles. He further argues in the Californian context that desalination, although depicted as a solution to the region's water crisis, serves as 'socioecological fix' which instead displaces and deepens crisis in the interest of economic growth. A similar argument is made by Scheba and Scheba (2018) in South Africa, where they argue that desalination is being adopted as an 'emergency quick fix' that primarily serves the interest of wealthier segments of the population and fits well into the dominant ecological modernization model of sustainable development. Using the example of Spain, Swyngedouw and Williams (2016) claim that increasing use of desalination reflects a process of depoliticization by eliminating conflict and thus the opportunity for political debate. In Singapore this has occurred at the geopolitical level, as desalination has enabled circumvention of problematic international relations with neighboring Malaysia from where some of its fresh water originates (Usher 2018). Desalination is often portrayed as a counter strategy to large scale infrastructure, but nonetheless offers technocratic solutions often justified on the basis of sustained economic growth. In line with the aforementioned concern about demand, Kallis (2008) warns that the 'urgency' of water crises can remove attention from drivers of water scarcity, and produce solutions that reinforce those drivers. Knights et al. (2007) also mention the risk of 'option foreclosing', meaning that alternatives (e.g. demand management, reusing storm- or wastewater) get outpaced by desalination's perceived benefits scalability and efficiency. This obscures the merits of those alternatives, including potential synergies between social, economic and environmental aspects (Knights et al. 2007).

Due to these problematic aspects, the WWF (Dickie 2007) as well as the World Bank (Schiffler 2004) frame desalination as the 'last option' that should only be applied if water saving strategies, effective resource management and efficiency-increasing measures have shown to be insufficient. Yet, considering the growth of desalination globally, it is questionable if it really is applied as the 'last option.' As shown here, desalination has various direct and indirect implications for all dimensions of sustainability, and Koontz and Hatfield (2016) emphasize the need for careful evaluation of desalination in comparison to other measures, and stress the importance of socioenvironmental context in such assessments.

\section{From 'last option' to 'an absolute must': benefits, drawbacks and decision-making surrounding desalination in Gotland}

As we now turn to the Gotland case, it is worth noting at the outset that we encountered relatively low levels of contention around desalination as a solution to Gotland's water scarcity problems - despite the rather 
unconventional decision-making process that preceded the construction of the Herrvik plant. Most participants above all appeared relieved that their water concerns had been partly resolved, even though there is a high level of awareness that desalination alone is not enough. However, deeper analysis revealed many limitations and drawbacks which might not have a significant impact today, but may likely to become problematic in the future - especially given the normalizing and depoliticizing tendencies within the decision-making process. To explain how we reached this conclusion, we will start by showing the reasoning behind the implementation of desalination.

\section{Gains for Gotland: unlimited water supply}

Four main lines of reasoning have had particular weight in the decision to construct the Herrvik plant.

First, there is the promise of quick and stable access to an infinite water resource. The purpose of desalination is of course to supply additional water to consumers, and water supply has to be designed for the highest consumption rates due to a lack of storage capacity (Region Gotland Teknikförvaltningen 2016a). Desalination is especially useful in summertime; tourism drastically increases the number of water users (representative LRF), and water is one of the most important prerequisites for a tourist destination (representative GFB). The Baltic Sea provides additional water in sufficient quantity (Region Gotland Teknikförvaltningen 2016a), and several respondents emphasized the unlimited potential supply of seawater. For example, the representative from the nature conservation society noted:

All the other water sources can fail and dry [out] but not the Baltic, that will [always] have water. (Representative NF 4/3/2017)

Desalination thus solves the problem of a water deficit, not least for the tourism industry, and makes water supply less tied to climatic variation. Many actors perceive a lack of precipitation as one of the major causes for severe water problems in recent years, and the engineers stated that dependence on rain is a general hazard for water supply. Region Gotland (2014) similarly highlights weather independency and operational reliability of desalination plants as major advantages. The politician MP added another dimension which we return to later: urgency. The rapid deterioration of water access in recent years required quick decision-making, despite the fact that all interviewees (except for GFB) considered Gotland's water problems to have been predictable.

Second, desalination is seen as a way to protect groundwater resources and prevent saltwater intrusion, which could destroy whole aquifers, by reducing the pressure on groundwater and preventing overuse. This rests on the logic that desalination will reduce groundwater withdrawal, while still ensuring drinking water supply (Region Gotland 2014 and 2018). This in turn relies on the assumption that groundwater takings are directly replaced by desalinated water, while the overall consumption remains stable (whether or not this is accurate remains to be seen, but an issue pointed out by the Aquabrava project is that residents with access to private groundwater wells and municipal water will still use groundwater for certain purposes, as it is free of charge, especially if desalination leads to higher costs).

Third, the quality of groundwater has sometimes caused problems in the past, whereas desalination enables the production of very clean water (Region Gotland Teknikförvaltningen 2016a). It also makes for easy adjustment of water hardness, which allows for reductions in detergent use, and can also decrease the copper content of sludge (Region Gotland Teknikförvaltningen 2016a). This helps addressing the issue of pollution of natural water sources.

Fourth, desalination reduces the role of water as an obstacle for future economic development. The LRF (farmers' association) representative pointed to benefits for the big water users, and they expect that tourism and agriculture will profit from more secure water supply. The water council Vattenråd ÖG added that the possibility to connect to the municipal system, which in some cases is directly linked to additional water supply by desalination, will raise the value of properties, thus benefitting individual land and property owners. Lack of water is hence not only perceived as problematic in relation to residents' needs, but also to the island's economic development. Of importance here is also the manner in which the region's development plans translate into 
solutions offered by those responsible for water supply at a more technical level. The engineers reported that the increase in tourism and industry requires new solutions for the "normal people", and that Gotland's development plans have put them under pressure to deliver solutions that clear the way for the future that these plans anticipate. They feel that water supply is not considered early enough in decision-making and planning processes, making it difficult to implement what has been decided in the political sphere. Water supply seems to be subordinated to broader development strategies, and the engineers are often given little time to react. Despite the predictability of water supply issues, then, solutions are often developed with a sense of urgency and desalination has provided the engineers with a relatively immediate solution that can be scaled up with growing demand. This recurrent issue of urgency is something we return to below.

Finally, different stakeholder groups offered a number of other arguments of more particular relevance to them. The engineers, for example, pointed to the ability to scale supply according to needs, the lack of feasible alternatives, and giving the authorities additional reasons to invest in pipe replacements (desalinated water requires modern pipes). The representatives for NF and LRF noted that desalination avoids land use conflicts, especially compared to wetland restoration. Desalination thus reduces the burden on decision-makers to position themselves regarding the priorities and legitimacies of different water and land uses. Finally, an important point made by several interviewees (the engineers, the politician MP, and representatives for LRF, NF and the County Administrative Board) is that despite all these benefits, desalination should still be a complement to other solutions. This suggests that many acknowledge the shortcomings of desalination, which we present next.

\section{Drawbacks and limitations of desalination}

We found that four types of concerns were evident in the documents analyzed, and/or were expressed by interviewees. Many can be recognized from the literature review presented above, but there is also important contextual dynamics at play.

As in other cases, desalination on Gotland is associated with a number of economic and environmental tradeoffs, including higher costs compared to conventional water supply measures, energy intensity, and the discharge of brine into the Baltic Sea. High energy input is mentioned as a drawback in many documents (Region Gotland Teknikförvaltningen 2016a; Region Gotland 2014, n.d.-b), albeit briefly and often in relation to cost. The purchase of membrane filters is also associated with cost (Region Gotland Teknikförvaltningen 2016a; Region Gotland 2014). Since construction, maintenance and water supply are financed by user fees, this means higher prices for consumers. Vattenråd ÖG sees the costs especially problematic in comparison to the use of groundwater:

It's not cost effective to have a plant running if you can have natural water [re]stored down in the ground. (Vattenråd ÖG, 7/3/2017)

We encountered very little discussion around how to solve these issues, except for one mention of solar panels. Discharge of brine was only mentioned by two interviewees; the politician MP and the Aquabrava project, who expressed concerns about potential long term damage to natural ecosystems.

Health concerns were also raised during stakeholder interviews. According to the politician MP, it had been mentioned in early discussions on desalination on Gotland that the water should be mixed with groundwater to raise the mineral content. However, there is no groundwater available in Herrvik, meaning that the desalinized water basically contains no minerals (politician MP, Vattenråd ÖG). This has led to concerns among consumers. The engineers and politician MP both described how the desalinated water initially reacted with the pipes, causing discolored, malodorous water. Lack of minerals also gives some people the impression of receiving water of lower quality. The engineers emphasized that the water fulfils WHO and the National Food Agency [Livsmedelsverket] regulations, and that their responsibility is to deliver water, not a pharmaceutical. However, others have questioned the appropriateness of current legislation, which only considers maximum values of drinking water components - not minimum concentrations of beneficial substances (Vattenråd ÖG, politician MP). This is not a completely novel issue; Rosborg (2015) describes potential negative health impacts from demineralized water and argues that legislation should be adapted to the 
technologies in use. The Aquabrava project criticized authorities for not taking these concerns seriously enough, and for not taking water samples from consumers to analyze their chemical content.

Demand-side impacts constitute a less direct, but often discussed, potential tradeoff of desalination. These were notably absent from documents, but were brought up by some interviewees. The LRF representative expressed concern that desalination can be misinterpreted as the ultimate solution, leading to less careful attention to the island's water resources and increased consumption. Indeed engineers expect increased water demand to result from implementation of desalination, although they assume that this will stabilize once the most attractive tourist areas have been developed (implying a direct correlation between desalination and tourism expansion). By contrast, Vattenråd ÖG anticipates that even per capita consumption will increase as water access improves. The NF representative expressed concern that desalination affects an important argument in the fight against the local mining industry (a contentious issue on Gotland for many years) and allows for continuation or even expansion of potentially water-damaging businesses. Their reasoning is that desalination may reduce the pressure on different actors to prove the legitimacy of their water use.

Finally, there are some important water-related issues that desalination is unable to solve - for example, high rainwater runoff into the sea due to wetland loss. While desalination provides people with tap water, several interviewees mentioned that it does not address problems related to lack of water in Gotland's natural environment. The politician MP argued that there is a risk that water-related ecosystem services are forgotten if desalination gets framed as the ultimate solution. The Aquabrava project and Vattenråd ÖG expressed similar concerns about wildlife and water needs of agriculture. The Vattenråd ÖG (water council) representative went as far as stating:

I think the biggest issue is not the drinking water. [...] The big problem is the nature, the forests, the fields, the crops, the wildlife, birds [...] and if we solve that then the drinking water problem will not be a problem (Vattenråd ÖG, 7/3/2017)

This statement problematizes the narrow perspective on water that desalination represents. A different but related concern is the high percentage of Gotland's population that is not connected to the municipal water supply. Several documents clearly state that authorities have no obligation to connect all properties to the municipal grid, nor do they have any motivation to do so in the future, primarily for economic reasons (Gotlands Kommun 2005 2010; Region Gotland 2014). While the municipal grid is expanding, individual water takings also expand due to the scattered settlements outside the grid expansion areas (Region Gotland 2014). Desalinated water adds to the municipal system, but $37 \%$ of Gotland's population still rely on individual wells, including most farmers and livestock owners (Gotlands Kommun 2010). Many of them are inadequately protected and suffer problems regarding water quantity and quality (Gotlands Kommun 2005, 2008, 2010) such as bacterial or pesticide contamination (Gotlands Kommun 2010; Region Gotland 2014). Many interviewees acknowledged these problems, which is one reason why desalination can only complement measures to improve groundwater availability and quality. However, there are many unresolved questions regarding who actually has responsibility to conduct such measures. While the municipality is accountable to subscribers of the municipal grid (Region Gotland, n.d.-a), it is unclear who is accountable to private well owners. Although the municipality officially has an obligation to secure their supply too (Gotlands Kommun 2010), the Aquabrava representative reported that none of six administration entities they had contacted wanted to confirm their responsibility for groundwater and groundwater recharge.

To be clear, implementation of desalination does not cause these problems. However, the fact that it does little to solve them raises the question of how well suited the deliberation and decision-making processes around water are to adequately incorporate the complexity and wide range of concerns presented here. This takes us to the final part of the analysis: the mechanisms at work in the decision-making process that ultimately resulted in implementation of desalination. 


\section{How desalination became irresistible: unpacking the decision-making mechanisms}

By combining our analysis of how benefits and drawbacks are perceived and framed with closer examination of how the decision-making process played out in practice, we can reach a deeper understanding of the mechanisms through which desalination came to be implemented as a partial solution to Gotland's water problems. We begin with two aspects that are well known from the broader political ecology of water literature, as outlined in Section 2: the framing of water scarcity (its drivers as well as consequences), and the workings of technocracy. Lastly we emphasize the gradual process of normalization that desalination has undergone, which may have important long term implications.

When it comes to the issue of problem framing, we observed some degree of naturalization of root causes, as well as one wherein the island's economic survival urgently depends on increased water supply. Many interviewees acknowledged various kinds of human-induced causes of water shortages like historic drainage, wastefulness, agriculture, tourism and limestone mining. Others were more prone to emphasize geological and climatic factors - causes outside the scope of human influence - and consequently emphasized that additional water must be provided from some external source. Documents generally mention a number of factors: hydraulic and climatic conditions, temporal and spatial distribution of water demand, and an overall increase in demand following population growth, climate change and tourism development. In contrast, some interviewees (politician MP, Vattenråd ÖG, Representatives LRF and NF) and documents (Gotlands Kommun 2005, 2010) stated that there is no lack of water per se, but that most of it is currently inaccessible for human consumption. As described previously, Gotland has high rates of runoff and limited capacity to capture and store it, but the conclusions drawn from this differ again. Vattenråd ÖG pointed to bad water management and a lack of reservoirs. The politician MP thought water was insufficiently appreciated, arguing for a new attitude towards water and water use which recognizes the value of storm- and wastewater, and acknowledging ecosystem services. In other words, while there is some naturalization of root causes in support of desalination, this is also challenged implicitly or explicitly by several actors.

There is no agreed-upon definition of water scarcity on Gotland, although the term is regularly used by different groups. However, a common understanding is that water scarcity means an insufficient amount of water to fulfil the demands of society and businesses. The (Green party) politician MP pointed out:

If we can't use water for our companies, our businesses, whatever, we won't be able to live in Gotland, because just drinking water is not sufficient for a livelihood. (politician MP, 2/3/2017)

This emphasizes that water is necessary for more than direct human consumption alone. It grants validity to the use of water for individual economic purposes - pointing to the high dependency of Gotland's main economic activities on secure water supply. This has created a great deal of urgency to find a way to avert water scarcity rapidly. Construction of new housing for permanent residents as well as for tourists is gathering pace across the island (Region Gotland 2014, n.d.-b). Region Gotland Teknikförvaltningen (2016a) states that due to construction pressure and the committed water connections exceeding current production capacities, an additional water need of at least 1.5 million $\mathrm{m}^{3} /$ year is estimated. This is a considerable increase (about $37.5 \%$ of the current municipal supply). Several interviewees (politician MP, County Administrative Board, NF, GFB, the engineers) and numerous documents acknowledged the dependency of Gotland's long term development on secure water supply, and its ability to maintain its tourist industry (Gotlands Kommun 2008, 2010; Region Gotland Teknikförvaltningen 2016a; Region Gotland 2014, n.d.-b). There appears to be wide consensus amongst stakeholders that water must not be a limiting factor for Gotland's plans to expand tourism and increase residential development, which also suggests expansion of the municipal water grid. Public water and sewage system expansion has permitted new construction in the past (Region Gotland 2014). As a consequence of these visions, the engineers expect an increase in water demand within the municipal system, and the search for additional groundwater sources has not been successful in the past. Instead, groundwater levels are decreasing. High water dependency clearly enforces the attractiveness of desalination, as its 'unlimited' water supply is in line with a potentially unlimited growth scenario. 
The technocratic elements of the debate result from the prominent role played by engineers in the decision-making process. The politician MP noted:

It's been engineers that have been trying to solve a very difficult situation with a lack of time and this is the solution that they came up with. (politician MP, 2/3/2017)

Indeed, the procedure was rather unconventional. Initially, the area around Herrvik was not planned to be expanded in terms of municipal water supply in the near future. The initiative to expand the municipal grid there came from a group of locals who formed an association to solve their water and sewage problems. The technical committee saw this as an opportunity to collaborate and secure supply for neighboring Katthammarsvik, which was already in their operational area, while simultaneously expanding the supply to Herrvik. Over time the project grew considerably, which required more financial input from the technical committee and thus reallocation of money from other projects. The protocols of the technical committee give insight into this process. An interesting aspect is that local participation was not considered necessary. While this might be justified in the case of Herrvik, being a small plant with little direct impact, it neglects the plant's door-opening function. Gotland's Vision 2025 states that:

citizens should feel involved, have the opportunity to influence the development of society and to take responsibility for this. This requires natural meeting places and meeting procedures. Open discussions and conversations are important for democracy and also for the people's basic trust in the democratic system. (Gotlands Kommun 2008: 16)

The long term water and wastewater plan even states that:

the consequences of a possible future water supply based on desalination of the Baltic must be preceded by thorough investigations with regard to quality issues, implementation issues and the economy. The technical and economic consequences should be discussed and considered in close cooperation between civil servants and politicians. (Region Gotland 2014: 17)

These principles were not followed in this case; by first implementing desalination on a small scale, political debate was to some extent sidestepped. This was not intentional, but rather resulted from the pressure and urgency felt by the engineers (see below). Nonetheless, some interviewees expressed discontent. The politician MP complained:

From a democratic perspective, this hasn't been processed correctly because what they decided in the technical committee should have been brought up to the local parliament. (politician MP, $2 / 3 / 2017)$

Even the local water council (Vattenråd ÖG) was not informed in the process, and perceives a general lack of interest in their work among local authorities. This reflects a bigger problem concerning communication and cooperation between different institutions, highlighted by several respondents (engineers, GFB, Aquabrava project). It is clear that for various reasons, the engineers of Region Gotland ended up playing a key role in the decision to initiate desalination in Herrvik, a role that continues to be central as additional facilities are in progress. Power has been shifted from elected officials towards technical experts, whose field of expertise and particular responsibilities have shaped the outcome in a manner that has implications beyond the Herrvik plant.

A closely related point concerns the assessment criteria used by authorities when weighing different options, and these were particularly influential as a result of the technocratic nature of the process. The prestudy for Visby's future water supply (Region Gotland Teknikförvaltningen 2016a) presents assessment criteria 
for water supply options (Table 3). Although this document specifically refers to the water supply for Visby, the rationale for decision-making applies across Gotland's water management in general.

\begin{tabular}{|l|l|}
\hline Factor & Criterion \\
\hline Time & Provision of the stated amount within three years. \\
\hline Weather dependence & Independence of precipitation and evaporation. \\
\hline Economy & $\begin{array}{l}\text { Production cost per unit in relation to conventional water production and } \\
\text { predictable factors which may significantly affect the investment costs in } \\
\text { relation to other options. }\end{array}$ \\
\hline Technic & Security of operation and security of supply. \\
\hline Amount & Provides the additional amount of $15,000 \mathrm{~m}^{3}$ per day to Visby. \\
\hline Quality & Supply of clean drinking water according to water quality legislations. \\
\hline Environment & Environmentally acceptable. \\
\hline
\end{tabular}

Table 3: Assessment criteria for water supply options in Region Gotland Teknikförvaltningen (2016a).

There is no further information on how these criteria are weighted but it is clear that they in and of themselves prioritize certain types of strategies. There are hort time restrictions, importance given to technical security, an ability to provide pre-defined flows, and especially independence from weather event. All of these favor constructed water supply systems. Environmental aspects are only considered by a vague criterion ('environmentally acceptable') that does not draw attention to the specific impacts of different alternatives. Consequently, desalination is seen as meeting all requirements except for its costs (Region Gotland Teknikförvaltningen 2016a). Additional advantages emphasized in the documents are that seawater is not requested by any other party (Gotlands Kommun 2005) and that plants require little space, thus avoiding conflicts over land (Region Gotland Teknikförvaltningen 2016a). Desalination thereby stands out as appealing from a technical and short term political perspective.

Finally, our analysis revealed a gradual normalization within local authorities, a process fueled by the sense of urgency caused by shortages in recent years. Desalination was mentioned as a potential component of future water supply in Gotland's 2005 water plan. However, this document simultaneously states that groundwater recharge is sufficient to fulfil the population's needs (Gotlands Kommun 2005). In the 2010 'Build Gotland' [Bygg Gotland] document desalination is discussed as a small scale option for individual supply, and only as a last option if neither municipal supply nor private wells are feasible (Gotlands Kommun 2010). Moreover, if used, an assessment must show that water needs cannot be fulfilled with groundwater, and that a daily minimum of 150 liters of groundwater per household must be guaranteed even if problems with desalination occur (Gotlands Kommun 2010). Later on, Region Gotland (2014) stated in their long term water and wastewater plan that access to water is limited, and that the conditions to completely or partly base future water supply on desalination should be investigated. The report implies that desalination is an inevitable component of municipal water supply to combat future water scarcities in summer, and suggests several facilities. This is in line with the introduction of the desalination plant in Kvarnåkershamn, where Region Gotland calls its construction an "absolute must to solve the future water supply" (Region Gotland 2018). Hence, within a decade, desalination changed from a vague idea of a small scale solution and a last resort, into a substantial and necessary pillar of future water supply.

\footnotetext{
${ }^{5}$ The amount here is specified for an investigation of water supply for Visby and would be different for other locations on the island, or even the whole island.
} 


\section{Concluding discussion and recommendations}

We have investigated the benefits and tradeoffs of seawater desalination as a strategy to solve regional water scarcity problems on the Swedish island of Gotland, and the mechanisms through which desalination came to be implemented and expanded. The case contains several important lessons of broader relevance for this particular technology, which is expanding rapidly around the world (Ghaffour et al. 2013), but also more generally for technological solutions to natural resource management problems. Desalination clearly fits into Dryzek's (2013) description of ecological modernization, where nature is mainly conceptualized as a source of resources (or absorbing waste) for humans. Economic growth is thereby taken for granted and is supposed to be aligned with environmental protection. More precisely, desalination constitutes a form of 'weak' ecological modernization which includes technocratic forms of decision-making as well as giving a prominent role to technology, to align human interests and environmental limits (Dryzek 2013). But the production and distribution of water intrinsically ties political decisions and priorities to material and biophysical outcomes, serving particular needs and interests. It is problematic, then, when such decisions are depoliticized - even if, as in this case, there is little visible controversy around them. Outcomes can be perceived as rational and inevitable solutions, instead of the choices they really are. Revisiting the overarching research question of why Gotland's authorities decided to complement the island's water supply with desalination despite its known controversies, we wish to highlight two aspects.

First, the anticipated benefits of desalination are in line with Gotland's broader development agenda, which centers on threatened water-reliant sectors. This dynamic of socioeconomically produced scarcity is a familiar one, although the specific causal drivers are contextual; others have noted for example how 'allegedly inevitable' suburbanization can result in an appeal for desalination (Otero et al. 2011). Desalination in theory provides endless water supply and thereby effectively dissolves the 'natural limit' to growth that water has historically posed (albeit a 'natural limit' that has been significantly altered by human activities). In light of these benefits, the drawbacks that have been considered have either been deemed acceptable or externalized, meaning that remaining problems are supposed to be addressed by additional measures. Work is underway to produce a more comprehensive regional water supply plan (Länsstyrelsen Gotland 2018) but this is not yet in place, and currently there appears to be a significant degree of uncertainty around who is responsible for ensuring a holistic strategy.

Second, due to the nature of the decision-making process there are concerns that were never given sufficient attention, and critical voices were unable to gain a prominent role. Stakeholder interviews and interactions with locals during fieldwork showed that generally, Gotland's society is perceived as benefiting from the desalination plants and the development they facilitate. Still, closer investigation made clear that this surface level support does not make the decision an unproblematic one, as several mechanisms served to depoliticize the process.

Our findings here align with, and adds deepened understanding of, earlier points made about the potential of desalination to obscure and sidestep tensions around water resources (see Scheba and Scheba 2018; Swyngedouw and Williams 2016). In the specific case of Gotland, this occurred through a combination of partial naturalization of water scarcity (Kallis 2008; Swyngedouw 2011), gradual normalization wherein the initial small scale plant played an important role, and technocratic thinking underpinned by a sense of urgency linked to the economic role of water. Urgency is a dangerous attribute in decision-making as it hinders timeconsuming yet important reflections and assessments (Kenis and Lievens 2014). In other words, political debate is sacrificed in favor of a quick solution. Moreover, it can direct awareness from problem drivers to solutions that potentially exacerbate underlying structural causes (Kallis 2008). In Gotland, there are clearly some important causal structures behind water scarcity problems which desalination does little to address. For example, desalination does not reduce the importance of protecting groundwater resources - especially since many people are (and will remain) outside the municipal grid. Desalination is not guaranteed to actually reduce pressure on groundwater, and it does not lessen the importance of wetland restoration, which appears to be a particularly promising long term strategy considering climate change projections. All these points were explicitly raised by interviewees who are active in the local setting, hence there is potential for critical dialogue.

Our point here is not that desalination should be dismissed because it does not account for all these aspects. Rather, our findings support McEvoy's (2015) argument that desalination, like any water technology, 
must be thought of as "embedded in complex social, political, and economic contexts" where neither positive outcomes (like aquifer protection) nor negative outcomes (like increased demand) are inherent. Specifically, we urge caution about the manner in which desalination is being normalized and the (explicit and implicit) criteria through which it is favored, especially as it can reduce the perceived importance of protective, restorative and demand-side strategies. This is particularly important given the growing interest in desalination that has been observed in Sweden, further spurred on by the 2018 drought (Andersson 2018).

Based on these insights, we make the following recommendations for policymakers and planners within and beyond the case of Gotland:

- Political dimensions of water production, use and allocation must remain central in decisionmaking, with open democratic deliberation on conflicts of interest and priorities. Benefits for certain groups should be made explicit, and drawbacks and limitations should be acknowledged so that measures like mitigation, compensation and complementary solutions can be discussed. Furthermore, it is important to be wary of the phenomenon of normalization.

- There is a need to be cognizant of tendencies to shift decision-making towards experts (e.g. engineers). Their knowledge and perspectives are important, but do not necessarily encompass the perspectives of the broader population, and they have not gained legitimacy through the votes of the public. It is also important to critically and continuously revisit assessment criteria used by experts, to ensure that these reflect values that are important to the public.

- Legislation surrounding water quality may need reviewing, concerning its ability to address challenges posed by new technologies, such as potential health consequences.

- For long term sustainability, water management cannot be separated from, and subordinated to, broader strategies for economic development. Sustainable water management may call for exploration of alternative development pathways that put less pressure on water and other resources. This potentially means accepting boundaries, and plan development within these ('backcasting'; see Gleeson et al. 2012) and may necessitate considerable restructuring of societal and economic configurations - questions which cannot be devolved to technical committees.

Our findings are based on a single case study, and the specific dynamics of the case should not be generalized. The conditions for democratic deliberation, for example, clearly differ substantially between countries and regions. However, by adopting a critical realist approach we sought to understand underlying mechanisms that are likely to exist in different configurations elsewhere, thus providing guidance for further research. The widely-noted issues of technocratic decision-making and discursive framing (of water scarcity, but also of what constitutes desirable social and economic development) warrant continued attention, but so does the less-discussed phenomenon of normalization. One important avenue would be to go beyond the decision-making process and those directly involved in it, to also explore broader dynamics of public discourse and mobilization (or lack thereof) around water alternatives in different sociopolitical contexts. For example, in Spain where desalination has had a much more prominent role than in Sweden thus far, Otero et al. (2011) note a growing popular movement for more democratic water management and alternative forms of development. Finally, as this study investigated an ongoing process where not all consequences are visible yet, we encourage scholars to revisit the case in the future - for example to examine water consumption patterns related to the implementation of bigger scale desalination or to investigate efforts for wetland restoration and water reuse systems alongside the desalination strategy. 


\section{References}

Anderson, J., S. Bassi, T. Dworak, M. Fergusson, C. Laaser, O. Le Mat, V. Mattei $\beta$ and P. Strosser. 2008. Potential impacts of desalination development on energy consumption. Vienna: Institute for European Environmental Policy.

Andersson, C.V. 2018. Allt fler vill dricka avsaltat havsvatten [More and more people want to drink desalinated $\begin{array}{llllll}\text { water]. } & \text { Sveriges } & \text { Radio. } & \text { [accessed } & \text { August } & 13\end{array}$ https://sverigesradio.se/sida/artikel.aspx?programid $=83$ andartikel $=6998008$

Asp, M., S. Berggreen-Clausen, G. Berglöv, E. Björck, J.E. Mårtensson, L. Nylén, A. Ohlsson, H. Persson and E. Sjökvist. 2015. Framtidens klimat i Gotlands län - enligt RCP-scenarier [Future climate in Gotland region - according to RCP-scenarios]. SMHI Klimatologi report series no 31.

Bakker, K. 2000. Privatizing water, producing scarcity: the Yorkshire drought of 1995. Economic Geography 76(1): 4-27.

Benton, T. and I. Craib. 2010. Philosophy of social science: the philosophical foundations of social thought. New York: Palgrave Macmillan.

Bowen, G.A. 2009. Document analysis as a qualitative research method. Qualitative Research Journal 9(2): $27-40$

Bryman, A. 2012. Social research methods (4th ed.). Oxford: Oxford University Press.

Cooley, H. and M. Heberger. 2013. Key issues for seawater desalination in California: energy and greenhouse gas emissions. Oakland, CA: Pacific Institute.

Dahlqvist, M., B. Thorsbrink, J. Holgersson, L. Nisell, L. Maxe and M. Gustafsson. 2017. Våtmarker och grundvattenbildning - om möjligheten till ökad kapacitet vid grundvattentäkter på Gotland [Wetlands and ground water formation - on the possibility for increased capacity of groundwater catchement areas on Gotland]. SGU report series No. 2017: 01.

Dickie, P. 2007. Making water: desalination: option or distraction for a thirsty world? Gland: WWF International.

Dryzek, J.S. 2013. The politics of the earth: environmental discourses. Oxford: Oxford University Press.

Feitelson, E. and A. Jones. 2014. Global diffusion of XL-capacity seawater desalination. Water Policy 16(6): 1031-1053.

Flyvbjerg, B. 2006. Five misunderstandings about case-study research. Qualitative Inquiry 2(2): 219-245.

Forsyth, T.J. 2001. Critical realism and political ecology. In Lopez, J. and G. Potter (eds.) After postmodernism: an introduction to critical realism. London: Athlone Press. Pp. 146-154.

Forsyth, T.J. 2003. Critical political ecology: the politics of environmental science. London: Routledge.

Fragkou, M.C. and J. McEvoy. 2016. Trust matters: why augmenting water supplies via desalination may not overcome perceptual water scarcity. Desalination 397: 1-8.

Fredelius, A. 2017. Nu avsaltar Öland havsvatten [Now Öland is desalinating sea water]. Dagens Industri [accessed August 13 2018] https://www.nyteknik.se/samhalle/nu-avsaltar-oland-havsvatten-6857517

Geological Survey of Sweden. 2016. Extremt låga grundvattennivåer [Extremely low groundwater levels] [accessed January 15 2017] http://www.sgu.se/om-sgu/nyheter/2016/mars/extremt-lagagrundvattennivaer/

Gezon, L.L. and S. Paulson (eds.). 2005. Political ecology across spaces, scales and social groups. New Brunswick: Rutgers University Press.

Ghaffour, N., T.M. Missimer and G.L. Amy. 2013. Technical review and evaluation of the economics of water desalination: current and future challenges for better water supply sustainability. Desalination 309: 197207.

Gleeson, T., W.M. Alley, D.M. Allen, M.A. Sophocleous, Y. Zhou, M. Taniguchi and J. Van der Steen. 2012. Towards sustainable groundwater use: setting long-term goals, backcasting, and managing adaptively. Ground Water 50(1): 19-26. 
Gleick, H. 2003. Global freshwater resources: soft-path solutions for the 21st century. Science 302(5650): 15241528.

Gotlands Kommun. 2005. Vattenplan för Gotlands kommun [Water plan for Gotland municipality]. https://www.gotland.se/servlet/GetDoc?meta_id=41892

Gotlands Kommun. 2008. Vision Gotland 2025 - Regionalt utvecklingsprogram för Gotland - RUP [Regional development plan for Gotland]. https://gotland.se/75704

Gotlands Kommun. 2010. Bygg Gotland - Översiktsplan för Gotlands kommun 2010-2025 [Build Gotland Overview plan for Gotland municipality]. https://www.gotland.se/50630

Greenlee, L.F., D. Lawler, B.D. Freeman, B. Marrot and P. Moulin. 2009. Reverse osmosis desalination: water sources, technology, and today's challenges. Water Research 43(9): 2317-2348.

Kaika, M. 2006. The political ecology of water scarcity: the 1989-1991 Athenian drought. In N. Heynen, M. Kaika and E. Swyngedouw (eds.) In the nature of cities: urban political ecology and the politics of urban metabolism. London: Routledge. Pp. 150-164.

Kallis, G. 2008. Droughts. Annual Review of Environment and Resources 33: 85-118.

Kenis, A. and M. Lievens. 2014. Searching for 'the political' in environmental politics. Environmental Politics 23(4): 531-548.

Knights, D., MacGill, I. and R. Passey. 2007. The sustainability of desalination plants in Australia: is renewable energy the answer? Paper presented at the OzWater Conference, Sydney, Australia.

Koontz, B. and T. Hatfield. 2016. The permitting of desalination facilities: a sustainability perspective. Journal of Environmental Health 79(4): 28-32.

Lior, N. 2017. Sustainability as the quantitative norm for water desalination impacts. Desalination 401: 99-111.

Länsstyrelsen Gotland. 2018. Regional vattenförsörjningsplan [Regional water supply plan]. http://www.lansstyrelsen.se/Gotland/Sv/miljo-och-klimat/vatten-ochvattenanvandning/Pages/vattenforsorjningsplan.aspx

Machin, A. and G. Smith. 2014. Ends, means, beginnings: environmental technocracy, ecological deliberation or embodied disagreement. Ethical Perspectives 21(1): 47-72.

March, H. 2015. The politics, geography, and economics of desalination: a critical review. Wiley Interdisciplinary Reviews: Water 2(3): 231-243.

Martinsson, M. 1997. Våtmarker på Gotland, Del 1 [Wetlands on Gotland, Part 1]. Länsstyrelsen i Gotland, $\begin{array}{lllll}\text { Livsmiljöenheten } & \text { report } & \text { No. } & \text { 8: } & \text { 1997. }\end{array}$ portal.org/smash/get/diva2:912823/FULLTEXT01.pdf

McEvoy, J. 2015. Can the adoption of desalination technology lead to aquifer preservation? A case study of a sociotechnical water system in Baja California Sur, Mexico. Water 7(10): 5224-5238.

Meerganz von Medeazza, G. 2005. "Direct" and socially-induced environmental impacts of desalination. Desalination 85(1): 57-70.

Miller, J.E. 2003. Review of water resources and desalination technologies. Sandia National Labs Unlimited release report SAND-2003-0800. https://prod.sandia.gov/techlib-noauth/access-control.cgi/2003/030800.pdf

Molle, F., P. Mollinga and R. Meinzen-Dick. 2008. Water, politics and development: introducing water alternatives. Water Alternatives 1(1): 1-6.

Otero, I., Kallis, G., Aguilar, R. and V. Ruiz. 2011. Water scarcity, social power and the production of an elite suburb: the political ecology of water in Matadepera, Catalonia. Ecological Economics 70(7): 12971308.

Region Gotland. 2014. Långsiktig plan för VA-utbyggnad på Gotland 2014-2022 [Long-term plan for expansion of water and sewage on Gotland]. https://www.gotland.se/52725

Region Gotland. 2017. Gotland i siffror [Gotland in figures]. http://www.gotland.se/64224

Region Gotland. 2018. Bräckvattenverk i Kvarnåkershamn [Desalination plant in Kvarnåkershamn] [Accessed August 8 2018] https://www.gotland.se/93575 
Region Gotland. n.d.-a. Gotlands grundvatten och dricksvatten - förutsättningar och utmaningar inför framtiden [Gotland's groundwater and drinking water - preconditions and challenges for the future]. https://www.gotland.se/94272

Region Gotland. n.d.-b. Information om Bräckvattenverket i Herrvik på Gotland - först i Sverige [Information about the desalination plant in Herrvik on Gotland - first in Sweden]. http://www.gotland.se/91546

Region Gotland Teknikförvaltningen. 2016a. Förstudierapport Visby framtida vattenförsörjning [Pre-study report Visby future water supply] (Unpublished).

Region Gotland Teknikförvaltningen. 2016b. Översyn av VA-planens del A. Verksamhetsplan. [Overview of water and sewage plan part A. Operational plan]. https://www.gotland.se/90147

Robbins: 2002. Obstacles to a First World political ecology? Looking near without looking up. Environment and Planning $A$ 34(8): 1509-1513.

Robbins: 2011. Political ecology: a critical introduction (2nd ed.). Chichester: Wiley.

Rosborg, I. 2015. Drinking water minerals and mineral balance. Cham: Springer.

Santos Pereira, S., Cordery, I. and I. Iacovides. 2009. Coping with water scarcity: addressing the challenges. Berlin: Springer.

Sayer, A. 2000. Realism and social science. London: Sage.

Scheba, S. and A. Scheba. 2018. Desalination as emergency fix: tracing the drought-desalination assemblage in South Africa. In J. Williams and E. Swyngedouw (eds.). Tapping the oceans: seawater desalination and the political ecology of water. Cheltenham : Edward Elgar. Pp. 98-120.

Schiffler, M. 2004. Perspectives and challenges for desalination in the 21st century. Desalination 65: 1-9.

Statistics Sweden. 2013. Land use in Sweden, $6^{\text {th }}$ edition. Report no MI03BR1301. http://www.scb.se/Statistik/_Publikationer/MI0803_2010A01B_BR_00_MI03BR1301.pdf

Statistics Sweden. 2019. Vattenuttag och vattenanvändning i Sverige [Water withdrawal and water use in Sweden] [Accessed January 24 2019] http://www.scb.se/mi0902

Steffen, W., K. Richardson, J. Rockström, S.E. Cornell, I. Fetzer, E.M. Bennett, R. Biggs, S.R. Carpenter, W. de Vries, C.A. de Wit, C. Folke, D. Gerten, J. Heinke, G.M. Mace, M. Persson, V. Ramanathan, B. Reyers. and S. Sörlin. 2015. Planetary boundaries: guiding human development on a changing planet. Science 347(6223): 1259855.

Sveriges Radio. 2018. Företagen som förbrukar mest kommunalt vatten [The companies that use the most $\begin{array}{llllll}\text { municipal } & \text { water] } & \text { [Accessed } & \text { January } & 20 & \text { 2019] }\end{array}$ https://sverigesradio.se/sida/artikel.aspx?programid=94andartikel $=6372386$

SVT. 2018. Norra Europas största bräckvattenverk byggs på Gotland [Northern Europe's largest desalination plant is built on Gotland] [Accessed August 28 2018] https://www.svt.se/nyheter/lokalt/ost/vattenverk1

Swedish Agency for Economic and Regional Growth. 2011. Tourism in Sweden. http://ec.europa.eu/regional_policy/sources/docgener/evaluation/library/sweden/1110_sweden tourism eval_en.pdf

Swyngedouw, E. 2009. The political economy and political ecology of the hydro-social cycle. Journal of Contemporary Water Research and Education 42(1): 56-60.

Swyngedouw, E. 2011. Depoliticized environments: the end of nature, climate change and the post-political condition. Royal Institute of Philosophy Supplement 69: 253-274.

Swyngedouw, E. 2013. Into the sea: desalination as hydro-social fix in Spain. Annals of the Association of American Geographers 103(2): 261-270.

Swyngedouw, E. and J. Williams. 2016. From Spain's hydro-deadlock to the desalination fix. Water International 41(1): 54-73.

Usher, M. 2018. Desali-nation: techno-diplomacy and hydraulic state restructuring through reverse osmosis membranes in Singapore. Transactions of the Institute of British Geographers 44(1): 110-124. 
Williams, J. 2018. Diversification or loading order? Divergent water-energy politics and the contradictions of desalination in southern California. Water Alternatives 11(3): 847-865.

World Water Assessment Programme. 2012. The United Nations world water development report 4, volume 2: Knowledge base. Paris: UNESCO.

Yin, R.K. 2009. Case study research: design and methods (4th ed.). London: Sage.

Zucchetto, J., and A.-M. Jansson. 1985. Resources and society: a systems ecology study of the island of Gotland, Sweden. New York: Springer.

Zarzo, D. and D. Prats. 2018. Desalination and energy consumption. What can we expect in the near future? Desalination 427: 1-9.

Zwarteveen, M.Z. and R. Boelens. 2014. Defining, researching and struggling for water justice: some conceptual building blocks for research and action. Water International 39(2): 143-158. 